Journal of Epidemiology and Public Health (2019), 4(2): 88-96

https://doi.org/10.26911/jepublichealth.2019.04.02.04

\title{
Multilevel Analysis on Determinants of Diarrhea in Demak, Central Java
}

\author{
Aulia Noorvita Ramadani'), Setyo Sri Rahardjo'), Bhisma Murti²) \\ 1)Masters Program in Public Health, Universitas Sebelas Maret \\ 2)Faculty of Medicine, Universitas Sebelas Maret
}

\begin{abstract}
Background: Diarrhea is an infectious disease with high mortality in Indonesia. Diarrhea often occurs where risk factor control is weak, such as in rural area. This study aimed to examine the determinants of diarrhea in Demak, Central Java.

Subjects and Method: A case control study was conducted in Demak, Central Java, in October to November 2018. A sample of 200 study subjects was selected by fixed disease sampling. The dependent variable was diarrhea. The independent variables were age, clean water supply, latrine availability, waste water management, waste management, hand wash behavior, family income, and education level. The data were collected by questionnaire and analyzed by a multilevel regression, run on Stata 13.

Results: Diarrhea increased with poor clean water supply $(b=1.45 ; 95 \% \mathrm{CI}=0.23$ to $2.67 ; \mathrm{p}=$ o.020), latrine unavailable $(\mathrm{b}=1.86 ; 95 \% \mathrm{CI}=0.66$ to $3.06 ; \mathrm{p}=0.002)$, poor waste management $(b=2.71 ; 95 \% \mathrm{CI}=1.52$ to $3.90 ; \mathrm{p}<0.001)$, poor garbage management $(\mathrm{b}=1.34 ; 95 \% \mathrm{CI}=0.17$ to $2.50 ; \mathrm{p}=0.024)$, irregular hand washing with soap $(\mathrm{b}=1.34 ; 95 \% \mathrm{CI}=0.12$ to $2.40 ; \mathrm{p}=0.030)$. Diarrhea decreased with high family income $(b=-1.56 ; 95 \% \mathrm{CI}=-2.78$ to $-0.34 ; \mathrm{p}=0.012)$ and high education $(b=-1.75 ; 95 \% \mathrm{CI}=-2.95$ to $-0.565 ; \mathrm{p}=0.004)$. Diarrhea was negatively associated with age but it was statistically non-significant $(b=-0.33 ; 95 \% \mathrm{CI}=-1.51$ to $0.844 ; \mathrm{p}=0.578)$. Village had contextual effect on the incidence of diarrhea (ICC $=13.9 \%)$.

Conclusion: Diarrhea increases with poor clean water supply, latrine unavailable, poor waste management, poor garbage management, irregular hand washing with soap. Diarrhea decreases with high family income and high education. Village has contextual effect on the incidence of diarrhea.
\end{abstract}

Keywords: diarrhea, water supply, hand wash behavior, waste management

\section{Correspondence:}

Aulia Noorvita Ramadani. Masters Program in Public Health, Universitas Sebelas Maret. Jl. Ir. Sutami 36 A, Surakarta, Central Java 57126. Email: aulia.noorviat@yahoo.com.

Mobile: +6285641577322 .

\section{BACKGROUND}

Diarrhea is liquid or soft defecation which can be water only and more often than usual (three or more times a day) (Sarmiento I et al., 2014). Diarrhea means watering more than four times a day, whether or not accompanied by mucus and blood or not. All age groups are attacked by diarrhea, both toddlers, children and adults (Akinyemi et al., 2017).
Diarrhea is still a world health problem and is one of the infectious diseases in which the mortality and illness is still relatively high. Diarrhea kills $15 \%$ of children or around 2,195 children every day more than AIDS, malaria and measles (WHO, 2017). Diarrhea is still an important public health problem because it is one of the contributors to the number of deaths and morbidity in various countries including Indonesia. Approximately 80\% of 
deaths occur in children younger than 5 years (Indonesian Health Profile, 2016).

Diarrhea problems in Indonesia often occur in the form of outbreaks. Outbreaks of diarrhea often occur, especially in areas where controlling risk factors are still low, such as villages with no advanced village status. This is because the status of nondeveloped villages has poor coverage of sanitation and sanitation behavior (Ministry of Health, 2016).

The incidence of national diarrhea results in the 2014 Diarrhea Morbidity Survey amounted to 270 / 1,000 residents and estimated the number of diarrhea sufferers in health facilities in 2016 was $6,897,463$ people. Whereas the number of diarrhea patients reported to be treated in health facilities was $3,198,411$ people or $46.4 \%$ of the target. This is because environment-based diseases are always included in the top 10 diseases in almost all public health Center in Indonesia, one of them is diarrhea (Indonesian Health Profile, 2016).

Nearly $60 \%$ of deaths from diarrhea are caused by unsafe drinking water, poor hygiene and sanitation. Washing hands with soap can reduce the risk of diarrhea by at least 40\%. Good sanitation, safe drinking water and proper disposal of human waste, including the availability of latrines are very important to stop the spread of diarrheal diseases in children and adults. If environmental factors are unhealthy because they are contaminated with diarrhea and accumulate with unhealthy human behavior, transmission of diarrhea can easily occur (Freeman et al., 2014).

The incidence of diarrhea in Demak Regency based on health center reports was 32,877 cases. Demak Regency has 249 villages with access to decent drinking water amounting to 718,171 inhabitants (63.59\%), residents with access to proper sanitation (healthy toilets) of 746,997 people (66.14\%) while from 249 villages only 1 village has become a village Community Based Total Sanitation (STBM) (0.40\%) and 44 villages (17.67\%) that have stopped defecating carelessly. The number of houses is 321,719 , which includes healthy homes 184,658 (70.09) (Health Profile of Demak Regency, 2017).

\section{SUBJECTS AND METHOD \\ 1. Study design \\ This was an analytic observational study with a case control design (Murti, 2017).}

\section{Population and sample}

The source population used in this study was diarrhea patients who were treated in Demak Regency. The sample at the first level was taken at the community level by determining the source population (Case and Control) using Fixed disease sampling totaling 1: 3 between the case group and the control group. The sampling technique at the second level follows the first level based on the village category as the nondeveloped (swadaya) village, the developing village (swakarsa), the developed village (self-sufficient).

\section{Study variables}

The dependent variable was diarrhea. The independent variables at level 1 were age, family income, education level, availability of clean water, availability of latrine, waste water management, management of trash bins. The independent variable at level 2 was village strata.

\section{Operational definition of variables}

Diarrhea was defined as a condition of defecation of more than 3 times per day with liquid concentrations both accompanied by mucus and blood or not.

The availability of clean water was defined as clean water and drinking water facilities that must meet health require- 
Journal of Epidemiology and Public Health (2019), 4(2): 88-96

https://doi.org/10.26911/jepublichealth.2019.04.02.04

ments of physical, biological, and chemical requirements.

The availability of latrines water was defined as a safe and convenient facility to use as a defecation place.

Waste water management water was defined as a means of removing water from households, industries and generally containing harmful substances or substances.

Waste management water was defined as a facility for storing unused substances or objects originating from households or industrial processes. The habit of washing hands was defined as an action to maintain one's cleanliness and health for physical well-being.

Age was defined as the age of the study subject. Family income was defined as a condition that describes the income of a husband, wife, or family member obtained through working carried out with monthly average income in the last 6 months.

The level of education was defined as the level of formal education that was last pursued by the study subjects. Village strata was defined as a village level that has certain potential.

\section{Study instruments}

Data related to family income, education level and age were obtained using a questionnaire. The data related to the availability of water, latrine availability, waste water management, management of trash bins, and hand washing using soap were collected using the observation sheet. Village strata data was obtained from annual reports from BAPERMAS.

\section{Data Analysis}

Univariate analysis was performed to see the frequency distribution and the percentage of the characteristics of the research subjects. Bivariate analysis was conducted to study the relationship between the incidence of diarrhea and independent variables using the chi-square test and calculation of odds ratios (OR) with a confidence level (CI) of 95\%. Furthermore, multivariate analysis was performed using a multilevel logistic regression.

\section{Research ethics}

Research ethics include informed consent, anonymity, confidentiality, and ethical clearance. Research ethics was obtained from Research Ethics Committee, Faculty of Medicine, Universitas Sebelas Maret, Surakarta, Central Java.

\section{Sample characteristics}

Table 1 showed sample characteristics. Table 1 showed that most of the sample was at age $\geq 18$ years $(63.5 \%)$ and education level was senior high school (44\%).

\section{Table 1. Sample characteristics}

\begin{tabular}{|c|c|c|}
\hline Characteristics & $\mathbf{n}$ & $\%$ \\
\hline \multicolumn{3}{|l|}{ Age } \\
\hline$<18$ years & 73 & 36.5 \\
\hline$\geq 18$ years & 127 & 63.5 \\
\hline \multicolumn{3}{|l|}{ Education } \\
\hline Primary school & 30 & 15.0 \\
\hline $\begin{array}{l}\text { Junior high } \\
\text { school }\end{array}$ & 29 & 14.5 \\
\hline $\begin{array}{l}\text { Senior high } \\
\text { school }\end{array}$ & 88 & 44.0 \\
\hline Diploma & 22 & 11.0 \\
\hline Bachelor & 31 & 15.5 \\
\hline
\end{tabular}

\section{Univariate analysis}

Table 2 showed the results of univariate analysis. Table 2 showed that as many as $63.5 \%$ had high income, $72.5 \%$ had good availability latrine, $70 \%$ good waste water management, $51 \%$ good waste management, and $64.5 \%$ good had washing using soap behavior. 
Table 2. The results of univariate analysis

\begin{tabular}{|c|c|c|}
\hline $\begin{array}{ll}\text { Variable } \\
\end{array}$ & $\mathbf{n}$ & $\%$ \\
\hline \multicolumn{3}{|l|}{ Clean water availability } \\
\hline Good & 153 & 76.5 \\
\hline Poor & 47 & 23.5 \\
\hline \multicolumn{3}{|l|}{ Latrine availability } \\
\hline Good & 145 & 72.5 \\
\hline Poor & 55 & 23.5 \\
\hline \multicolumn{3}{|l|}{ Waste water management } \\
\hline Good & 140 & 70.0 \\
\hline Poor & 60 & 30.0 \\
\hline \multicolumn{3}{|l|}{ Waste management } \\
\hline Good & 102 & 51.0 \\
\hline Poor & 98 & 49.0 \\
\hline \multicolumn{3}{|l|}{ Washing hand with soap } \\
\hline Good & 129 & 64.5 \\
\hline Poor & 71 & 35.5 \\
\hline \multicolumn{3}{|l|}{ Family Income } \\
\hline Low & 73 & 36.5 \\
\hline High & 127 & 63.5 \\
\hline \multicolumn{3}{|l|}{ Education } \\
\hline Low & 59 & 29.5 \\
\hline High & 141 & 70.5 \\
\hline \multicolumn{3}{|l|}{ Village Strata } \\
\hline Swadaya & 120 & 60.0 \\
\hline Swakarsa & 32 & 16.0 \\
\hline Swasembada & 48 & 24.0 \\
\hline \multicolumn{3}{|l|}{ Diarrhea } \\
\hline No & 150 & 75.0 \\
\hline Yes & 50 & 25.0 \\
\hline
\end{tabular}

\section{Bivariate analysis}

Table 3 showed the result of bivariate analysis. Table 3 showed that poor clean water supply $(\mathrm{OR}=5.81 ; 95 \% \mathrm{CI}=2.84$ 11.89; $\mathrm{p}<0.001)$, poor latrine availability $(\mathrm{OR}=3.54 ; 95 \% \mathrm{CI}=1.79-7.00 ; \mathrm{p}<0.001)$, poor waste water management $(\mathrm{OR}=11.66$; 95\% CI $=5.55$ to $24.49 ; \mathrm{p}<0.001)$, poor waste management $(\mathrm{OR}=3.65 ; 95 \% \mathrm{CI}=$ 1.81 to $7.33 ; \mathrm{p}<0.001)$, did not wash hand using soap $(\mathrm{OR}=3.55 ; 95 \% \mathrm{CI}=1.82$ to 6.90; $\mathrm{p}<0.001$ ) increased the risk of diarrhea.

High education $(\mathrm{OR}=0.18 ; 95 \% \mathrm{CI}=$ 0.91 to $0.36 ; \mathrm{p}<0.001)$ and high income $(\mathrm{OR}=0.09 ; \quad 95 \% \quad \mathrm{CI}=0.04$ to 0.20 ; $\mathrm{p}<0.001)$ reduced the risk of diarrhea.

\section{Multivariate analysis}

Table 4 showed the results of multilevel logistic regression. Table 4 showed that diarrhea was positively affected by poor water supply $(b=1.45 ; 95 \% \mathrm{CI}=0.23$ to 2.67; $\mathrm{p}=0.020$ ), poor latrine availability $(b=1.86 ; 95 \% \mathrm{CI}=0.66$ to $3.06 ; \mathrm{p}=0.002)$, poor waste water management $(b=2.71$; 95\% $\mathrm{CI}=1.52$ to $3.90 ; \mathrm{p}<0.001$ ), poor waste management $(b=1.34 ; 95 \% \mathrm{CI}=0.17$ to 2.50; $\mathrm{p}=0.024)$, and poor washing hand behavior $(b=1.34 ; 95 \% \mathrm{CI}=0.12$ to 2.40 ; $\mathrm{p}=$ 0.030).

Diarrhea was negatively affected by high family income $(b=-1.56 ; 95 \% \mathrm{CI}=$ 2.78 to $-0.34 ; \mathrm{p}=0.012$ ) and high education level $(b=-1.75 ; 95 \% \mathrm{CI}=-2.95$ to $-0.57 ; \mathrm{p}=$ 0.004). Diarrhea was negatively affected by age but it was statistically non-significant $(b=-0.33 ; 95 \% \mathrm{CI}=-1.51$ to $0.844 ; \mathrm{p}=$ 0.578). Village had contextual effect on incidence of diarrhea with ICC $=13.9 \%$. 
Table 3. The result of bivariate analysis

\begin{tabular}{|c|c|c|c|c|c|c|c|c|c|}
\hline \multirow{2}{*}{$\begin{array}{l}\text { Independent } \\
\text { Variables }\end{array}$} & \multicolumn{2}{|c|}{$\begin{array}{c}\text { No } \\
\text { Diarrhea }\end{array}$} & \multicolumn{2}{|c|}{ Diarrhea } & \multicolumn{2}{|c|}{ Total } & \multirow{2}{*}{$\mathbf{O R}$} & \multirow{2}{*}{$\begin{array}{l}95 \% \\
\mathbf{C I}\end{array}$} & \multirow{2}{*}{$\mathbf{p}$} \\
\hline & $\mathbf{n}$ & $\%$ & $\mathbf{n}$ & $\%$ & $\mathbf{n}$ & $\%$ & & & \\
\hline \multicolumn{10}{|l|}{ Clean water supply } \\
\hline Good & 128 & 83.7 & 25 & 16.3 & 153 & 100 & \multirow[t]{2}{*}{5.81} & $2.84-$ & \multirow[t]{2}{*}{$<0.001$} \\
\hline Poor & 22 & 46.8 & 25 & 53.2 & 47 & 100 & & 11.89 & \\
\hline \multicolumn{10}{|l|}{ Latrine availability } \\
\hline Good & 119 & 82.1 & 26 & 17.9 & 145 & 100 & \multirow[t]{2}{*}{3.54} & $1.79-$ & \multirow[t]{2}{*}{$<0.001$} \\
\hline Poor & 31 & 56.4 & 24 & 43.6 & 55 & 100 & & 7.00 & \\
\hline \multicolumn{10}{|l|}{$\begin{array}{l}\text { Waste water } \\
\text { management }\end{array}$} \\
\hline Good & 125 & 89.3 & 15 & 10.7 & 140 & 100 & \multirow[t]{2}{*}{11.66} & $5 \cdot 55-$ & \multirow[t]{2}{*}{$<0.001$} \\
\hline Poor & 25 & 41.7 & 35 & 58.3 & 60 & 100 & & 24.49 & \\
\hline \multicolumn{10}{|c|}{ Waste management } \\
\hline Good & 88 & 86.3 & 14 & $13 \cdot 7$ & 102 & 100 & \multirow[t]{2}{*}{3.65} & $1.81-$ & \multirow[t]{2}{*}{$<0.001$} \\
\hline Poor & 62 & 63.3 & 36 & 36.7 & 98 & 100 & & $7 \cdot 33$ & \\
\hline \multicolumn{10}{|l|}{$\begin{array}{l}\text { Hand wash using } \\
\text { soap }\end{array}$} \\
\hline Good & 108 & 83.7 & 21 & 16.3 & 129 & 100 & \multirow[t]{2}{*}{3.55} & $1.82-$ & \multirow[t]{2}{*}{$<0.001$} \\
\hline Poor & 42 & 59.2 & 29 & 40.8 & 71 & 100 & & 6.90 & \\
\hline \multicolumn{10}{|l|}{ Age } \\
\hline$<18$ years old & 54 & 74.0 & 19 & 26.0 & 73 & 100 & \multirow[t]{2}{*}{0.91} & $0.47-$ & \multirow[t]{2}{*}{0.932} \\
\hline$\geq 18$ years old & 96 & 75.6 & 31 & 24.4 & 127 & 100 & & 1.77 & \\
\hline \multicolumn{10}{|l|}{ Family income } \\
\hline Low & 35 & 47.9 & 38 & 52.1 & 73 & 100 & \multirow[t]{2}{*}{0.09} & $0.04-$ & \multirow[t]{2}{*}{$<0.001$} \\
\hline High & 115 & 90.6 & 12 & 9.4 & 127 & 100 & & 0.20 & \\
\hline \multicolumn{10}{|l|}{ Educational level } \\
\hline Low & 30 & 50.8 & 29 & 49.2 & 59 & 100 & \multirow[t]{2}{*}{0.18} & $0.91-$ & \multirow[t]{2}{*}{$<0.001$} \\
\hline High & 120 & 85.1 & 21 & 14.9 & 141 & 100 & & 0.36 & \\
\hline
\end{tabular}

Table 4. The Result of Multilevel Logistic Regression

\begin{tabular}{|c|c|c|c|c|}
\hline \multirow[b]{2}{*}{ Independent variables } & \multirow[b]{2}{*}{ b } & \multicolumn{2}{|c|}{$95 \%$ CI } & \multirow[b]{2}{*}{$\mathbf{p}$} \\
\hline & & $\begin{array}{l}\text { Lower } \\
\text { limit }\end{array}$ & $\begin{array}{c}\text { Upper } \\
\text { limit }\end{array}$ & \\
\hline \multicolumn{5}{|l|}{ Fixed Effect } \\
\hline Clean water supply & 1.45 & 0.23 & 2.67 & 0.020 \\
\hline Latrine availability & 1.86 & 0.66 & 3.06 & 0.002 \\
\hline Waste water management & 2.71 & 1.52 & 3.90 & $<0.001$ \\
\hline Waste management & 1.34 & 0.17 & 2.50 & 0.024 \\
\hline Hand wash by using soap & 1.34 & 0.12 & 2.40 & 0.030 \\
\hline Age & -0.33 & -1.51 & 0.844 & 0.578 \\
\hline Family income & -1.56 & -2.78 & -0.34 & 0.012 \\
\hline Educational level & -1.75 & -2.95 & -0.56 & 0.004 \\
\hline \multicolumn{5}{|l|}{ Random Effect } \\
\hline Village strata & 0.53 & 0.03 & 0.87 & \\
\hline \multicolumn{5}{|l|}{$\begin{array}{l}\text { n observation }=200 \\
L \text { o likehood }=-5220\end{array}$} \\
\hline Log likehood = -52.20 & & & & \\
\hline \multicolumn{5}{|c|}{ LR test vs. Logistic regression, chibar2 $(O 1)=0.45$} \\
\hline \multicolumn{5}{|l|}{$\mathrm{p}=0.252$} \\
\hline $\mathrm{ICC}=13.9 \%$ & & & & \\
\hline
\end{tabular}




\section{DISCUSSION \\ 1. The effect of clean water supply on diarrhea}

Based on the result of this study, there was a significant effect of clean water availability on the incidence of diarrhea $(\mathrm{OR}=$ 4.06; $\mathrm{p}=0.013$ ).

Consuming unhygienic drinking water increased the risk of diarrhea in children (Hasan and Richardson, 2017). A study by Samwel et al. (2014) stated that household characteristic that had a statistically significant effect on the incidence of diarrhea was drinking water. This study was in line with the study by Bitew et al. (2017) which showed that the use of unprotected sources of clean water and inadequate drinking water services would increase the risk of diarrhea in toddlers.

\section{The effect of latrine availability on diarrhea}

The result of this study showed that latrine availability were positively associated with diarrhea $(\mathrm{OR}=6.33 ; \mathrm{p}=0.002)$. Similar study by George (2014) reported that there was a significant effect of latrine availability and diarrhea $(\mathrm{p}=0.024)$. The result of this study was in line with a study by Fauziah et al. (2014) which showed that children under five who came from family which used one latrine for all family members were more likely to have diarrhea (6.5\%) for urban and rural area. This was due to the fact that latrines which were used by many people usually have a low level of sanitation, so that diarrhea germs would easily pollute the source of water, eating and drinking equipment through the hands of toilet users.

\section{The effect of waste water manage- ment on diarrhea}

The result of this study showed that there was a significant effect of waste water management on the incidence of diarrhea $(\mathrm{OR}=14.29 ; \mathrm{p}<0.001)$.
This study was in line with a study by Maharani and Yusiana (2013) which showed that there was an effect of waste water management on the incidence of diarrhea. The distance of wells from the sources of pollution such as waste water disposal in neighbourhood, landfills and cattle pen that were less than 10 meters were more likely to be contaminated by dirty water which resulted in polluted and unhygienic water sources that can affect water quality physically and microbiologically. Various seeds or germs that can live in the source of water were some of the causes of diarrhea in toddlers in the working area of Kambang Health Center (Minister of Health, 2017).

\section{The effect of waste management on diarrhea}

The result of this study showed that there was a significant effect of waste management on diarrhea $(\mathrm{OR}=3.74 ; \mathrm{p}=0.019)$.

This study was in line with a study by Imada and Muniz (2016) showed that 85 (96.6\%) study subjects had poor waste management. In fulfilling good waste management, each house must provide temporary waste storage with the construction that fulfill the requirements (strong and not easy to leak) and the trash can must be cleaned every day so that vectors or flies did not land on the trash can.

\section{The effect of washing hand using soap on diarrhea}

The result of this study showed that there was a significant effect of washing hand using soap on diarrhea $(\mathrm{OR}=3.39$; $\mathrm{p}=$ 0.023).

A study by Roman et al. (2017) showed that washing hand with soap after defecation was a protective factor for the incidence of diarrhea and it was statistically significant. The habit of washing hands that fulfill health requirements by using soap has become a routine that was conducted before 
Journal of Epidemiology and Public Health (2019), 4(2): 88-96

https://doi.org/10.26911/jepublichealth.2019.04.02.04

eating and after defecation. The role of the government also contributed to promote the Handwashing with Soap (CTPS) counseling program so that the public understood the benefits of good and proper hand washing by using soap, therefore, it could influence the results of this study (Minister of Health, 2017).

\section{The effect of age on the incidence of diarrhea}

The results of this study showed that there was a negative association between age and diarrhea $(\mathrm{OR}=0.62 ; \mathrm{p}=0.365)$. Someone who was $>18$ years old was less likely to have diarrhea.

This was supported by a study by Desta et al. (2017) which stated that age did not have a significant effect on the incidence of diarrhea $(p=0.297)$. Severe diarrhea caused fluid loss, and can be lifethreatening, especially in children and people who were malnourished or have weak immunity. People with severe malnutrition have an increased risk of acute infectious diseases and death (Thiam et al., 2017). People who were malnourished were more likely to experience persistent diarrhea, and thin people have a higher risk of experiencing diarrhea that developed into persistent diarrhea (Roman and Ascp, 2017).

\section{The effect of family income on diarrhea}

The results of this study showed that there was a significant effect of family income on diarrhea $(\mathrm{OR}=0.24 ; \mathrm{p}=0.008)$.

The result of this study was in line with a study by Imada and Muniz (2017) which stated that the probability of diarrhea in children from poor households was 1.63 times $(\mathrm{OR}=1.63 ; 95 \% \mathrm{CI}=1.12$ to 2.36$)$ higher than children from rich family. People from rich households tend to adopt better hygiene and environmental sanitation behaviors and became their standard of living so they could prevent the occurrence of diarrhea.

\section{The effect of educational on diarrhea}

Based on the result of this study, there was a significant effect of education on the incidence of diarrhea $(\mathrm{OR}=0.18 ; \mathrm{p}=0.003)$ which mean that people who have high level of education were $82 \%$ protected from diarrhea.

A study done by Zeleke and Alemu (2014) showed thatthe average reduction in diarrhea episodes was 1.68 times less likely in the intervention group, which was the group that had higher education in the risky population at home. Educational factor was a very important element because by having an education, someone can receive more information, especially in maintaining personal and family health and broadening the horizons of thinking so that it was easier to develop themselves in preventing the transmission of an illness and obtaining competent medical care (Susanti and Sunarsih, 2016). This illustrated that the higher the education, the lower the risk of suffering from diarrhea, because highlyeducated people could take diarrhea prevention measures and conduct clean and healthy life behaviors (Santosa et al., 2014).

\section{The effect of village strata on diarrhea}

The results showed that the village conditions in each strata had a contextual effect on the occurrence of diarrhea by $13.9 \%$, so it was very important to note.

Low environmental quality was a potential condition to become a source of diarrhea transmission (Patil et al., 2014). Slum environmental conditions have a high risk of diarrhea cases because they were associated with poor sanitation and housing facilities (Adane et al., 2017). 


\section{REFERENCES}

Adane M, Mengistie B, Kloos H, Medhin G, Mulat W (2017). Sanitation facilities, hygienic conditions, and prevalence of acute diarrhea among under- five children in slums of Addis Ababa, Ethiopia: Baseline survey of a longitudinal study. PLoS ONE 12(8): e0182783. https://doi.org/10.1371/journal.pone.0182783 1-18.

Akinyemi AI, Adeniyi FF, Elizabeth O, Adebayo SO, Agunbiade OM (2017). Diarrhea management practices and child health outcomes in Nigeria: Sub-National Analysis. Advances in Integrative Medicine. 5(1): 15-22. doi.org/10.1016/j.aimed.2017.10.002.

Bitew BD, Woldu W, Gizaw Z (2017). Childhood diarrheal morbidity and sanitation predictors in a nomadic community. Ital J Pediatr. 43(91): 18. doi: 10.1186/s13052-017-0412-6.

Dinkes Provinsi Jateng (2017). Profil Kesehatan Provinsi Jawa Tengah Tahun 2016. Semarang.

Desta BK, Assimamaw NT, Ashenafi TD (2017). Knowledge, practice, and associated factors of home-based management of diarrhea among caregivers of children attending underfive clinic in Fagita Lekoma District, Awi Zone, Amhara Regional State, Northwest Ethiopia. Nursing Research and Practice. 10-12. https://doi.org/10.1155/2017/8084548

Fauziah A, Ahmad LAI, Tina L (2016). Studi Komparatif Determinan Kejadian Diare Di Wilayah Pesisir (Puskesmas Abeli). https://www.neliti.com/journals/jimkesmas 1-13.

George CM, Perin J, Karen J, Calani ND, Norman WR, Perry H, Davis TP, Erik DL (2014). Risk Factors for Diarrhea in Children under Five Years of Age Residing in Peri-urban Communities in Cochabamba, Bolivia. Am J Trop Med Hyg. 91(6): 1190-1196. doi: 10.4269/ajtmh.14-0057.

Hasan M, Richardson A (2017). How sustainable household environment and knowledge of healthy practices relate to childhood morbidity in South Asia : analysis of survey data from Bangladesh, Nepal and Pakistan. BMJ Open. 7(6):e015019. doi: 10.1136/bmjopen2016-015019.

Imada KS, Muniz PT (2016). Socioeconomic, hygienic, and sanitation factors in reducing diarrhea in the Amazon. Rev Saude Publica. 50(77): 1-10. doi: 10.1590/S1518-8787.2016050006505 .

Kemenkes RI (2016). Profil Kesehatan Indonesia 2015. Jakarta

Kemenkes RI (2017). Data dan Informasi Kesehatan Profil Kesehatan Indonesia 2016. Jakarta.

Lowe B, Lohse A, Andresen V, Vettorazzi E, Rose M, Broicher W (2016). The Development of Irritable Bowel Syndrome: A Prospective CommunityBased Cohort Study. Am J Gastroenterol. 111(9): 1320-9. doi: 10.1038/ajg.2016.255.

Mengistie B, Berhane Y, Worku A (2013). Prevalence of diarrhea and associated risk factors among children under-five years of age in Eastern Ethiopia: A Prevalence of diarrhea and associated risk factors among children under-five years of age in Eastern Ethiopia: A cross-sectional study. Open Journal of Preventive Medicine. 3(7): 446-453. doi: 10.4236/ojpm.2013.37060.

Setiani DMW, Yusiana MA (2013). Lack of mother's personal hygiene related to diarrhea. Jurnal Penelitian Stikes RS Baptis Kediri. 6(1): 119-128. ISSN 2085-0921.

Merga N, Alemayehu T (2015). Knowledge, 
Journal of Epidemiology and Public Health (2019), 4(2): 88-96

https://doi.org/10.26911/jepublichealth.2019.04.02.04

perception, and management skills of mothers with under-five children about diarrhoeal disease in indigenous and resettlement communities in assosa district, western ethiopia. J Health Popul Nutr. 33(1): 20-30.

Mohammed S, Tamiru D (2014). The burden of diarrheal diseases among children under five years of age in arba minch district, southern ethiopia and associated risk factors: a crosssectional study. International Scholarly Research Notices. http://dx.doi.org/10.1155/2014/654901.

Mukti DA, Raharjo M, Dewanti NAY (2016). Hubungan antara penerapan program sanitasi total berbasis masyarakat ( stbm ) dengan kejadian diare di wilayah kerja puskesmas. Jurnal Kesehatan Masyarakat. 4(3): 767-775. ISSN: 2356-3346.

Mumtaz Y, Zafar M, Mumtaz Z (2014). Knowledge attitude and practices of mothers about diarrhea in children under 5 years. Journal of Dow University of Health Sciences. 8(1): 3-6. ISSN: 2410-2180.

Murti B (2017). Prinsip dan metode riset epidemiologi. Edisi kedua. Program Studi Ilmu Kesehatan Masyarakat Program Pascasarjana Universitas Sebelas Maret: Yuma Pustaka. ISBN: 978-602-71484-2-0.

Patil SR, Arnold BF, Salvatore AL, Briceno
B, Ganguly S, John M, Paul JG (2014). The effect of india's total sanitation campaign on defecation behaviors and child health in rural madhya pradesh: a cluster randomized controlled trial. 11(8). doi: 10.1371/journal.pmed.1001709.

Roman C, Solh T, Broadhurst M (2017). Infectious diarrhea. 2(2): 229-245. doi: 10.1016/j.cpha.2016.12.006.

Samwel M, Eddison M, Faith N, Richard S, Elizabeth KM, Douglas N (2014). Determinants of diarrhea among young children under the age of five in Kenya, evidence from KDHS 200809. African Population Studies Etude de la Population Africaine. 28(2). Doi: https://doi.org/10.11564/28-0-556.

Thiam S, Aminata ND, Samuel F, Winkler MS, Ibrahima S, Jacques AN, Christian S, Penelope V, Utzinger J, Faye O, Cissee G (2017). Prevalence of diarrhoea and risk factors among children under five years old in mbour, senegal: a cross-sectional study. infectious diseases of poverty. Infect Dis Poverty. 1-12. Doi: 10.1186/s40249017-0323-1.

Zeleke AT, Alemu ZA (2014). Determinants of under-five childhood diarrhea in Kotebe health. 14(4). Global Journal of Medical Research: B Pharma, Drug Discovery, Toxicologgy and Medicine. 14 (4): 1-7. 